\title{
Predictors of Intention to Donate Blood among the Eligible Population in Dire Dawa Administration, Eastern Ethiopia: Using the Theory of Planned Behaviour
}

Shibeshi KA ${ }^{1^{*}}$ and Ibrahim NA ${ }^{2}$

${ }^{1}$ Department of Medicine, College of Medicine and Health Science, Diredawa University, Diredawa, Ethiopia

${ }^{2}$ Department of Midwifery, College of Medicine and Health Science, Diredawa University, Diredawa, Ethiopia

"Corresponding author: Ketema Ayele Shibeshi, Department of Medicine, College of Medicine and Health Science, Diredawa University, Diredawa, Ethiopia, Tel: +251937282987; E-mail: Ketemaayele@ymail.com

Received date: September 12, 2018; Accepted date: September 30, 2018; Publication date: October 07, 2018

Copyright: $\odot 2018$ Shibeshi KA, et al. This is an open-access article distributed under the terms of the Creative Commons Attribution License, which permits unrestricted use, distribution, and reproduction in any medium, provided the original author and source are credited.

\section{Abstract}

Background: Human blood is an element of human life. Blood Donation can save million lives and cannot be manufactured. WHO estimates that blood donation by $1 \%$ of the population is generally the minimum needed to meet a nation's most basic requirements for blood and advocates an annual $3 \%$ to $5 \%$ of the healthy population to maintain an ideal stock of blood and blood products to keep up with its consumption. Thus, aim of this study is to assess intention of blood donation among eligible blood donors in Dire Dawa City, Eastern Ethiopia.

Methods: Community based cross-sectional study design was conducted from January 1 to 30, 2017. Data were collected face to face from a sample size of 1021 using pretested structured questionnaire. A multistage sampling method was employed to identify the source population and study subjects were selected by systematic sampling. Multiple logistic regression analysis with an entry of 0.05 and 0.1 removals for controlling possible effect of confounders and considered statistically significant at $p$-value of $<0.05$.

Result: Of all 1021 respondents, 969 (95\%) were participated in the study and of them less than half $426(44 \%)$ of them had intention of blood donation in the future but there was limited means of information dissemination, misconception about of blood donation. In multivariate analysis age, residents, occupation, income and perceived behavioural control were statistically significance association with intention of blood donation.

Conclusion: Intension of blood donation in the future is poor. Thus relevant authorities should have to work collaboratively with stake holders and community guards to improving means of information dissemination and participation to increase intention of blood donation.

Keywords: Intension of blood donation; Body fluid; Blood donations

Abbreviations: ATB: Attitude Towards Behaviour; DDRHB: Dire Dawa Regional Health Bureau; ERCS: Ethiopian Red Cross Society; FMoH: Federal Ministry of Health: LMIC: Low- and Middle-Income Countries; MMR: Maternal Mortality Rate; NBBE: National Blood Bank of Ethiopia; PBC: Perceived Behavioural Control; SN: Subjective Norm

\section{Introduction}

Blood is a specialized body fluid in humans that delivers necessary substances such as nutrients and oxygen to the cells and transports metabolic waste products away from those same cells and it is an element of human life [1]. WHO estimates that blood donation by $1 \%$ of the population is generally the minimum needed to meet a nation's most basic requirements for blood [2]. WHO advocates an annual donation of blood by $3 \%$ to $5 \%$ of the healthy population in order to maintain an ideal stock of blood and blood products to keep up with its consumption [3]. Because millions of lives lost each year due to lack of blood and blood products for transfusions, and most of them happen in developing countries [1]
Blood is collected from voluntary non-remunerated donors that is one of the four components of WHO's internal strategy to promote global safety and minimize risk associated with transfusion. Blood safety is obtained from low risk and regular donors, who donate blood at least once in a year [4]. However, annually 81 million units of blood are collected all over the world and only 27 million were collected in LMIC, where by $82 \%$ of the world's population lives [5]. This is improved by establishing an inventory with safe and enough blood donations [6]. In Sub-Saharan Africa an estimated 18 million units of safe blood per year is needed, merely about $15 \%$ were collected [4]. Ethiopia is the second most populous country in the continent $[7,8]$; a country with high MMR of 412/100,000 live birth which accounted for $21 \%$ of all deaths and the highest in the world [9-11] and high motor vehicle accident among ten top countries in the world [12] and a large non immune population for malaria [13].

Blood transfusion is a life-saving intervention that is the process of receiving blood products and used in persons who lost large volumes of blood from serious accidents, obstetric and gynaecological haemorrhages, or surgery, stem cell transplant patients, symptomatic anaemia from medical or hematologic conditions or cancers to replace lost components of the blood in patient management within health care systems. One does not know who will need blood transfusion 
Citation: Shibeshi KA, Ibrahim NA (2018) Predictors of Intention to Donate Blood among the Eligible Population in Dire Dawa Administration, Eastern Ethiopia: Using the Theory of Planned Behaviour . J Blood Disord Transfus 9: 410. doi:10.4172/2155-9864.1000410

Page 2 of 8

tomorrow [14-16]. Quarter million maternal death in the world and $15 \%$ of child mortality in Africa were due to obstetric bleeding and anaemia, in which blood transfusion is always required [4]. Globally, around 92 million unit blood donations are collected annually from blood donors [17]. Despite of this fact, only 27 million are collected in low and middle-income countries, whereby $82 \%$ of the world's population lives [5].

According to WHO, the statistic of blood collection per year for most of the developing countries showed that, the countries only capable to collect $45 \%$ of blood product annually [18]. Blood donation rates in Africa is estimated to be 5/1000 populations compared with developed countries which is $47 / 1000$ population in USA [19] in Ethiopia, of 200,000 units of blood needed annually, 87,000 units of blood were donated for transfusion [20]. Even though there is much effort done to boost the participation of the society to involve in blood donation, but, still the amount of blood is under a required level [21]. Because demand for transfusion continues to rise especially in health care setting and a steady decline in voluntary non- remunerated blood donation $[6,22,23]$. Blood is vital for saving life of an individual and blood donation is a self-directed volunteer service that can only be obtained from generous donors since it cannot be manufactured. There is no sufficient data throughout Ethiopia including the study area to have adequate blood donations to save the life of many women's, children's and patients who required blood transfusion. Most of the researches done were institutional based and in urban areas only. But the current research was conducted both in urban and rural areas by using a well-tested theory of planned behaviour in order to clearly determine the intention of blood donation of the community. Thus, knowing the intention of the community towards blood donation and predictors for intention is very important for the development of strategies in order to collect adequate amount of blood that will helps to save millions of life in the country as well as the local administrative councils.

\section{Methods and Materials}

Dire-Dawa is one of the cities which are found in the Eastern part of Ethiopia $515 \mathrm{~km}$ away from the main city Addis Ababa. The total population of Dire-Dawa is estimated according to Dire-Dawa Health Bureau 2009 report is 466,000 with almost equal in male and female distribution. The total number of population who live in urban is 315,937 and the rest 150, 063 live in rural Kebeles. There are a total of 38 rural and 9 urban Kebele regarding health facilities there are 2 urban hospitals, 15 health centres and 32 health posts and there is also one blood bank which is responsible to collect blood. Community based cross sectional study design was employed from January 1 to 30 , 2017. The required sample size was determined by using double population proportion estimating formula considering the community based research conducted in Mekele city administration assumed to be $37 \%$ of the populations had intention of blood donation [24] and 50\% was considered for rural community because of there is no research conducted in the rural area. Thus, the proportion was Confidence interval of $95 \%$, Margin of error $5 \%$, and Non- response rate of $5 \%$. The desired power: $80 \%$ power $=>0.84$ was taken and considering design effect of 2, making the final of 1021 .

All eligible Dire Dawa administrative council population age between 18 to 65 years for blood donation were included in the study. Those adults were selected by multi-stage sampling technique that lived in the study area for at least six months were included. The total number of population in selected Kebeles were $\mathrm{N}=221,924$. The study employed a multistage sampling technique was used to obtain a representative sample of the study participants in the communities where the study were carried out as follows: at stage one; we have divided the population into urban and rural. There are 9 kebeles in urban and 38 kebeles in rural found. Based on the population availability the number of individuals involved in the study 327 (32\%) from rural and 694 (68\%) from urban were proportionately allocated. At stage two; a sampling frame of all the local administrative districts in the region was prepared and then 4 Kebeles (the lowest administrative unit in Ethiopia) were selected from the total of 9 kebeles of the urban. (kebele $2=170$, kebele $5=112$, kebele $7=142$, kebele $9=270$ and from 38 rural kebeles which are divided into four clusters 12 kebeles (three kebeles taken from each cluster) were selected by lottery method. Cluster Melkajebdu (Adiga felema $=22$, Hulla Hului=29, Aselisso=25; Cluster Biyo Awale (Kalicha health centre $=23$, Bishan Baha $=32$, Biyo Awale health centre=34) ; Cluster Wahil (Wahil health centre $=30$, Dujuma $=22$, Jelo Belina health centre $=37$ ); Cluster Jeldessa(lege dini $=20$, Melka Kero health centre $=22$, Jeldessa health centre $=31$ ) Systematic random sampling technique was used to select households with proportional allocation to the population size of the selected kebeles both in urban and rural. Finally, lottery method was employed to select one study participant for households if there were more than one eligible individual (aged 18-65 years old).

Data were collected by face-to-face interview using a structured pretested questionnaire. The questionnaire was first prepared in English and translated to Amharic, then translated back to English by another person to check for its consistency. The questionnaire had five sections comprising; Socio-demographic factors (age, sex, marital status, religion, monthly income, educational status and occupation), behavioural factors, Knowledge questions consists seven items, practice question consists a total of 5 items, Interviewer guided structured questionnaire of cognitive constructs was used to collect the data at each selected household with a total of 31 items with five level likert scale of 5 strongly agree and 1 is strongly disagree for the questions. Intention to blood donation (3 questions), attitude to blood donation direct and indirect (12 questions) and subjective norm direct and indirect (10 questions) of blood donation, perceived behavioural control (2 questions), and 4 questions of self-efficacy developed after reviewing of relevant literatures [6-8] and adapted to the context of the study area. Ten diploma nurses' data collectors and $3 \mathrm{BSc}$ nurses were recruited as supervisors. The quality of data was assured by proper designing by using $10 \%$ pre-tested questionnaire and made amendment based on the obtained information. Two days training were given for the data collectors and supervisors by the principal investigator for a day just before and a day after the protest. Prior to analysis, data were cleaned, coded, checked for normality, completeness. The data were entered using Epi data 3.1 and exported to SPSS windows V. 21.0 for analysis. The findings of the study are presented by using tables and graphs. Bivariate analysis was used primarily to check which variables have association with the dependent variable individually and then variables were entered into multiple logistic regressions with an entry of 0.05 and 0.1 removals for controlling the possible effect of confounders. Finally, the variables with $\mathrm{p}$-value of $<0.05$ were considered statistically significant. Spearman Rank Order Correlation Coefficient statistic was used to examine the association between the constructs of ATB, SN and PBC with the intention to donate blood. In addition, the degree of association between independent and dependent variables was assessed using AOR: with 95\% CI. 
Citation: Shibeshi KA, Ibrahim NA (2018) Predictors of Intention to Donate Blood among the Eligible Population in Dire Dawa Administration, Eastern Ethiopia: Using the Theory of Planned Behaviour . J Blood Disord Transfus 9: 410. doi:10.4172/2155-9864.1000410

Page 3 of 8

Ethical clearance was obtained from Ethical Review Committee of Dire Dawa University, College of Medicine and Health Science and formal letter of cooperation was written to respective officials of the study area. After explaining the purpose of study, data collectors obtained voluntary verbal consent from each study participant and clearly told that they had full right to refuse or withdraw from the study at any time of the interview. Confidentiality of information was kept including omitting personal identifier such as the name of the respondents.

\section{Results}

\section{Socio-demographic characteristics}

In this study, about 969 subjects were participated with a response rate of $95 \%$. Most $438(45.2 \%)$ of the participants were female and majority 397 (41\%) of them were age 26-35 years, nearly more than half $531(54.8 \%)$ were male and $276(28.5 \%)$ were private employee; regarding marital status majority $546(56.3 \%)$ were married and a total of 299 (30.9\%) were within primary educational status; the vast majority were Muslim in religion and Oromo in ethnicity $581(60 \%)$ and $523(52.6 \%)$ respectively (Table 1$)$.

\section{Knowledge on various blood donations}

321 (33.1\%) of the participants were aware of the normal amount of blood donation at one time (300 to $450 \mathrm{ml}$ ); for duration of donated blood stayed on the shelf 445 (45.9\%) said for 3 months, majority 702 $(72.4 \%)$ of the respondents were believed that the body produced or replaced periodically the lost blood, regarding the minimum weight required for blood donation 207 (21.4\%) know correctly which is $45 \mathrm{~kg}$ half of respondents 495 (51\%) were mentioned blood donation required for patients. Majority 654 (67.5\%) of the respondents said that most appropriate age categories for blood donation were age b/n 18-35 years (Table 2).

\begin{tabular}{|c|c|c|c|}
\hline Variable & Category & $(n=969)$ & $\%$ \\
\hline \multirow{5}{*}{ Age } & $18-25$ & 291 & 30 \\
\hline & $26-35$ & 397 & 41 \\
\hline & $36-45$ & 195 & 20.1 \\
\hline & $46-55$ & 56 & 5.8 \\
\hline & $>56$ & 30 & 3.1 \\
\hline \multirow{2}{*}{ Sex } & Male & 531 & 54.8 \\
\hline & Female & 438 & 45.2 \\
\hline \multirow{6}{*}{ Occupation } & Student & 128 & 13.2 \\
\hline & Private employee & 276 & 28.5 \\
\hline & Gov't employee & 138 & 14.2 \\
\hline & Merchant & 39 & 4 \\
\hline & House wife & 108 & 11.1 \\
\hline & Peasant & 188 & 19.4 \\
\hline \multirow{2}{*}{ Marital status } & Single & 303 & 31.3 \\
\hline & Married & 546 & 56.3 \\
\hline
\end{tabular}

\begin{tabular}{|c|c|c|c|}
\hline & Divorced & 83 & 8.6 \\
\hline & Widowed & 37 & 3.8 \\
\hline \multirow{5}{*}{ Educational status } & Illiterate & 230 & 23.7 \\
\hline & 1-8 grade & 299 & 30.9 \\
\hline & $9-12$ grade & 246 & 25.4 \\
\hline & Diploma & 129 & 13.3 \\
\hline & Degree \& above & 65 & 6.7 \\
\hline \multirow{4}{*}{ Religion } & Muslim & 581 & 60 \\
\hline & Orthodox & 320 & 33 \\
\hline & Protestant & 60 & 6.2 \\
\hline & Catholic & 8 & 0.8 \\
\hline \multirow{6}{*}{ Ethnicity } & Somali & 113 & 11.4 \\
\hline & Oromo & 523 & 52.6 \\
\hline & Amhara & 229 & 23 \\
\hline & Harari & 25 & 2.5 \\
\hline & Gurage & 37 & 3.7 \\
\hline & Other & 42 & 4.2 \\
\hline \multirow{2}{*}{ Resident } & Urban & 649 & 67 \\
\hline & Rural & 320 & 33 \\
\hline \multirow{4}{*}{ Income } & $<500$ & 158 & 15.9 \\
\hline & $500-1000$ & 118 & 11.9 \\
\hline & $1001-1500$ & 275 & 27.6 \\
\hline & $>1500$ & 418 & 42 \\
\hline
\end{tabular}

Table 1: Socio demographic characteristics of adults on predictors of intention to donate blood in Dire Dawa administration 2018.

\begin{tabular}{|c|c|c|c|}
\hline Variables & Category & $(n=969)$ & $\%$ \\
\hline \multirow{5}{*}{$\begin{array}{l}\text { Time of donated blood stayed on the } \\
\text { shelf }\end{array}$} & 1 month & 222 & 22.9 \\
\hline & 2 month & 237 & 24.5 \\
\hline & 3 month & 445 & 45.9 \\
\hline & Don't know & 36 & 3.7 \\
\hline & $>3$ months & 29 & 3 \\
\hline \multirow{2}{*}{ Our body produces blood periodically } & Yes & 702 & 72.4 \\
\hline & No & 267 & 27.6 \\
\hline \multirow{4}{*}{ Minimum weight for blood donation } & $<45 \mathrm{~kg}$ & 407 & 42 \\
\hline & $45 \mathrm{~kg}$ & 207 & 21.4 \\
\hline & $50 \mathrm{~kg}$ & 216 & 22.3 \\
\hline & $55 \mathrm{~kg}$ & 112 & 11.6 \\
\hline
\end{tabular}


Citation: Shibeshi KA, Ibrahim NA (2018) Predictors of Intention to Donate Blood among the Eligible Population in Dire Dawa Administration, Eastern Ethiopia: Using the Theory of Planned Behaviour . J Blood Disord Transfus 9: 410. doi:10.4172/2155-9864.1000410

Page 4 of 8

\begin{tabular}{|l|l|l|l|}
\hline \multirow{4}{*}{$\begin{array}{l}\text { Amount blood donate at one time in } \\
\mathrm{ml}\end{array}$} & $60 \mathrm{~kg}$ & 27 & 2.8 \\
\cline { 2 - 4 } & $300-450 \mathrm{ml}$ & 321 & 33.1 \\
\cline { 2 - 4 } & $500 \mathrm{ml}$ & 314 & 32.4 \\
\cline { 2 - 4 } & $200 \mathrm{ml}$ & 289 & 29.8 \\
\cline { 2 - 4 } & Don't know & 45 & 4.6 \\
\hline \multirow{5}{*}{ Period of blood donation } & Every week & 62 & 6.4 \\
\cline { 2 - 4 } & Every 3 monthly & 414 & 42.7 \\
\cline { 2 - 4 } & Every 6 monthly & 319 & 32.9 \\
\cline { 2 - 4 } & Every one year & 156 & 16.1 \\
\hline & Don't know & 18 & 1.9 \\
\hline \multirow{5}{*}{ Blood donation mostly need for } & Patient & 495 & 51.1 \\
\cline { 2 - 4 } & Laboring women & 311 & 32.1 \\
\cline { 2 - 4 } & $\begin{array}{l}\text { Blood loss with } \\
\text { accident }\end{array}$ & 152 & 15.7 \\
\cline { 2 - 4 } & Other & 11 & 1.1 \\
\hline
\end{tabular}

Table 2: Knowledge description of respondents on blood donation in Dire Dawa administration 2018.

\section{Information on blood donation}

Nine hundred sixteen $(94.5 \%)$ of the participants were heard about blood donation from different sources, majority 656 (67.7\%) heard from Television and the least sources of information were from flyers $80(8.3 \%)$. Of the respondents $50(5.2 \%)$ didn't heard any information about blood donation through out there life time, but the largest 597 (61.7\%) participants heard from single source which was Television, 41 (4.2\%) of them said that they heard from more than two sources which were TV, Radio, and Health professional. $65.1 \%$ of respondents replied that age greater than 18 years were eligible to donate blood. On the contrary the highest respondents 958 (98.1\%) responded that person who previously receive blood, and least 609 (62.8\%) pregnant or lactating mothers should not have to donate blood.

\section{History of blood donation}

$718(74.1 \%)$ of the respondents did not have history of blood donation throughout their lives, the reasons given was $76(7.6 \%)$ lack of having any detail information about blood donation, $84(8.4 \%)$ fear of blood loss, 138 (13.9\%) because of different diseases and 417 (41.7\%) had mentioned different reasons. 123 (12.7\%) of respondents either their families or themselves had required blood donation among them $70(7.7 \%)$ were obtained directly from blood bank without replacement and the remained 53 (5\%) were obtained from blood bank with replacements from their families.

Direct subjective norms Two hundred (20.6\%) respondents perceived that the referents others doesn't support their blood donation whereas $166(17.1 \%)$ perceived that their referents support blood donation. According to TPB explanation behaviour is outside volitional control thus, in this research 409 (42.2\%) of respondents perceived that it is easy and $190(19.6 \%)$ were difficult for them to get blood collectors. Majority 693 (71.5\%) of respondents had showed positive attitude towards blood donation of them 391 (91.8\%) had high intention of blood donation. Regarding self-efficacy, three forth 739 (76.3\%) of respondents had moderate self-efficacy towards blood donation of whom 340 (79.8\%) had high intention of blood donation in the coming six months.

\section{Magnitude and factors associated with intention to donate blood voluntarily}

The participant's intention was measured using weighted mean and the overall intention to donate blood in the next 6 months was neutral which was 10.09 ( \pm SD 3.15). And 426 (44\%) of respondents had high intention to give blood. A comparison of the profiles of respondents who had high and low intention, from 649 urban dwellers 329 (50.7\%) and out of 320 rural residence 97 (30.3\%) of them had high intention to donate blood for the coming 6 months.

\section{Factors influencing intention of blood donation}

Bivirate analysis: Finding from bivariate logistic regression analysis showed that age, sex, residents, educational status, marital status, occupation, income, direct subjective norms, perceived behavioural control, Attitude and Self-efficacy were significant associated with intention to donate blood (Table 3).

\begin{tabular}{|c|c|c|c|c|c|}
\hline \multirow[t]{2}{*}{ Variables } & \multirow[t]{2}{*}{ Categories } & \multicolumn{2}{|l|}{ Intention } & \multirow[t]{2}{*}{ p-value } & \multirow[t]{2}{*}{ COR at $\mathrm{Cl}(95 \%)$} \\
\hline & & High $n=426(44 \%)$ & Low $n=543(56 \%)$ & & \\
\hline \multirow[t]{5}{*}{ Age } & $18-25$ & $161(37.8)$ & $130(23.9)$ & 1 & - \\
\hline & $26-35$ & $177(41.5)$ & $220(40.5)$ & 0.005 & $0.650(.479, .881)$ \\
\hline & $36-45$ & $73(17.1)$ & $122(22.5)$ & 0.000 & $0.483(.333, .700)^{*}$ \\
\hline & $46-55$ & $11(2.6)$ & $45(8.3)$ & 0.000 & $0.197(.098, .397)^{*}$ \\
\hline & $>=56$ & $4(1.0)$ & $26(4.8)$ & 0.000 & $0.124(.042, .365)^{*}$ \\
\hline \multirow[t]{2}{*}{ Sex } & Female & $216(50.7)$ & $222(40.9)$ & 1 & - \\
\hline & Male & $210(49.3)$ & $321(49.1)$ & 0.002 & $1.487(1.152,1.920)^{*}$ \\
\hline Residence & Rural & $97(22.8)$ & $223(41.1)$ & 1 & - \\
\hline
\end{tabular}


Citation: Shibeshi KA, Ibrahim NA (2018) Predictors of Intention to Donate Blood among the Eligible Population in Dire Dawa Administration,

\begin{tabular}{|c|c|c|c|c|c|}
\hline & Urban & $329(77.2)$ & $320(58.9)$ & 0.000 & $2.364(1.780,3.139)^{*}$ \\
\hline \multirow[t]{4}{*}{ Marital status } & Single & $179(40.0)$ & $124(22.8)$ & 1 & - \\
\hline & Married & $222(52.1)$ & $324(59.7)$ & 0.000 & $0.475(.357, .632)^{\star}$ \\
\hline & Divorced & $20(4.7)$ & $63(11.6)$ & 0.000 & $0.220(.127, .382)^{\star}$ \\
\hline & Widowed & $5(1.2)$ & $32(5.9)$ & 0.000 & $0.108(.041, .286)^{*}$ \\
\hline \multirow[t]{5}{*}{ Education } & Illiterate & $41(9.6)$ & $189(34.8)$ & 1 & - \\
\hline & Primary & $116(27.2)$ & 183(33.7) & 0.000 & $2.922(1.939,4.403)^{*}$ \\
\hline & Secondary & $140(32.9)$ & $106(19.6)$ & 0.000 & $6.088(3.994,9.281)^{*}$ \\
\hline & Diploma & $78(18.3)$ & $51(9.4)$ & 0.000 & $7.050\left(4.326,11.490^{\star}\right)$ \\
\hline & Degree/above & $51(12)$ & $14(2.6)$ & 0.000 & $16.793(8.499,33.179)^{*}$ \\
\hline \multirow[t]{7}{*}{ Occupation } & Student & $84(19.7)$ & $44(8.1)$ & 1 & - \\
\hline & Private & $137(32.2)$ & $139(25.6)$ & 0.003 & $0.516(.334, .797)^{\star}$ \\
\hline & Govlt & $97(22.8)$ & $41(7.6)$ & 0.415 & $1.239(.740,2.076)$ \\
\hline & Peasant & $28(6.6)$ & $160(29.5)$ & 0.000 & $0.092(.053, .158)^{\star}$ \\
\hline & Other & $26(6)$ & $66(12.2)$ & 0.000 & $0.206(.115, .369)^{*}$ \\
\hline & House wife & $37(8.7)$ & $71(13)$ & 0.000 & $0.273(.159, .468)^{\star}$ \\
\hline & Merchants & $17(4)$ & $22(4)$ & 0.015 & $0.405(.195, .840)^{*}$ \\
\hline \multirow[t]{4}{*}{ Income } & $>500$ & $38(8.9)$ & $120(22.1)$ & 1 & \\
\hline & $500-1000$ & $52(12.2)$ & $66(12.2)$ & 0.001 & $2.488(1.487,4.164)^{*}$ \\
\hline & $1001-3000$ & $111(26.1)$ & $164(30.2)$ & 0.001 & $2.137(1.380,3.309)^{*}$ \\
\hline & $>=3001$ & $225(52.8)$ & $193(35.5)$ & 0.000 & $3.681(2.437,5.561)^{*}$ \\
\hline \multirow[t]{3}{*}{ Attitude } & Negative & $4(0.9)$ & $43(7.9)$ & 1 & - \\
\hline & Neutral & $31(7.3)$ & $198(36.5)$ & 0.350 & $1.683(.565,5.017)$ \\
\hline & Positive & $391(91.8)$ & $302(55.6)$ & 0.000 & $13.918(4.942,39.200)^{*}$ \\
\hline \multirow[t]{3}{*}{ Subjective norm (SN) } & Negative & $34(8)$ & $166(30.6)$ & 1 & - \\
\hline & Neutral & $270(63.4)$ & $335(61.7)$ & 0.000 & $3.935(2.632,5.884)^{*}$ \\
\hline & Positive & $122(28.6)$ & $42(7.7)$ & 0.000 & $14.182(8.525,23.594)^{\star}$ \\
\hline \multirow{3}{*}{$\begin{array}{l}\text { Perceived } \\
\text { control (PBC) }\end{array}$} & Difficult to control & $9(2.1)$ & 181(33.3) & 1 & - \\
\hline & Moderate to control & $58(13.6)$ & $312(57.5)$ & 0.000 & $3.739(1.809,7.724)^{*}$ \\
\hline & Easy to control & $359(84.3)$ & $50(9.2)$ & 0.000 & $144.398(69.459,300.187)^{\star}$ \\
\hline \multirow[t]{3}{*}{ Self-efficacy } & Low & $29(6.8)$ & $102(18.8)$ & 1 & - \\
\hline & Moderate & $340(79.8)$ & $399(73.5)$ & 0.000 & $2.997(1.936,4.640)^{*}$ \\
\hline & High & $57(13.4)$ & $42(7.7)$ & 0.000 & $4.773(2.690,8.471)^{\star}$ \\
\hline
\end{tabular}

Table 3: Factors influencing intention to donate blood among adults in Dire Dawa, 2018.

Multiple logistic regressions: In the multivariable logistic regression analysis sex, residents, educational status, income and perceived behavioural control statistically significantly associated with intention to donate blood donation in the future. Accordingly, being male were
1.742 times more likely to intended to donate blood than female respondents $(\mathrm{AOR}=1.742 ; 1.104,2.749)$. Respondents who were living in urban were 2.537 times more likely to donate blood than those living in rural residents $(\mathrm{AOR}=2.537 ; 1.158,5.558)$. Participant's 
Citation: Shibeshi KA, Ibrahim NA (2018) Predictors of Intention to Donate Blood among the Eligible Population in Dire Dawa Administration, Eastern Ethiopia: Using the Theory of Planned Behaviour . J Blood Disord Transfus 9: 410. doi:10.4172/2155-9864.1000410

Page 6 of 8

educational status with primary, secondary, diploma, degree and above was $3.984,4.675,4.693$ and 12.051 times more likely to donate blood than illiterate participants respectively. Participants who earn 500-1000 birr, 1000-3000 birr and more than 3000 birr per month were 2.777 , 3.074 and 3.614 time more likely intended to donate blood than those who earn less than 500 Ethiopian birr. Besides participants who perceived to donate blood is easy were 109 times more likely and moderately to control situations for blood donation were 2 times more likely intends to donate blood than who perceived difficult to handle the circumstances for blood donation. (AOR=109.9, CI $(48.12,251.06)$ and $(\mathrm{AOR}=2.84, \mathrm{CI}(1.29,6.28)$ respectively (Table 4$)$.

\begin{tabular}{|c|c|c|c|c|c|c|}
\hline \multirow{2}{*}{$\begin{array}{l}\text { Variables } \\
\text { Categories }\end{array}$} & \multicolumn{2}{|l|}{ Intention } & \multirow[t]{2}{*}{$p$-value } & \multirow{2}{*}{ COR at $\mathrm{Cl}(95 \%)$} & \multirow{2}{*}{ p-value } & \multirow{2}{*}{ AOR at $\mathrm{Cl}(95 \%)$} \\
\hline & High $n=426(44 \%)$ & Low $n=543(56 \%)$ & & & & \\
\hline \multicolumn{7}{|l|}{ Sex } \\
\hline Female & $216(50.7)$ & $222(40.9)$ & 1 & - & 1 & - \\
\hline Male & $210(49.3)$ & $321(49.1)$ & 0.002 & $1.487(1.152,1.920)^{*}$ & 0.017 & $1.742(1.104,2.749) *$ \\
\hline \multicolumn{7}{|l|}{ Residence } \\
\hline Rural & $97(22.8)$ & $223(41.1)$ & 1 & - & 1 & - \\
\hline Urban & $329(77.2)$ & $320(58.9)$ & 0 & $2.364(1.780,3.139)^{*}$ & 0.02 & $2.537(1.158,5.558)^{* *}$ \\
\hline \multicolumn{7}{|l|}{ Education } \\
\hline Illiterate & $41(9.6)$ & $189(34.8)$ & 1 & - & 1 & - \\
\hline Primary & $116(27.2)$ & $183(33.7)$ & 0 & $2.922(1.939,4.403)^{\star}$ & 0 & $3.984(1.873,8.473)^{\star *}$ \\
\hline Secondary & $140(32.9)$ & 106(19.6) & 0 & $6.088(3.994,9.281)^{\star}$ & 0 & $4.675(2.021,10815)^{* *}$ \\
\hline Diploma & $78(18.3)$ & $51(9.4)$ & 0 & $7.050\left(4.326,11.490^{*}\right)$ & 0.001 & $4.693(1.821,12.094)$ ** \\
\hline Degree \& above & $51(12)$ & $14(2.6)$ & 0 & $16.793(8.499,33.179)^{*}$ & 0 & ${ }_{* *}^{12.051}(3.869,37.542)$ \\
\hline \multicolumn{7}{|l|}{ Income } \\
\hline$>500$ & $38(8.9)$ & $120(22.1)$ & 1 & - & 1 & - \\
\hline $500-1000$ & $52(12.2)$ & $66(12.2)$ & 0.001 & $2.488(1.487,4.164)^{\star}$ & 0.024 & $2.777(1.142,6.754)$ ** \\
\hline $1001-3000$ & $111(26.1)$ & $164(30.2)$ & 0.001 & $2.137(1.380,3.309)^{\star}$ & 0.004 & $3.074(1.443,6.551) * *$ \\
\hline$>=3001$ & $225(52.8)$ & 193(35.5) & 0 & $3.681(2.437,5.561)^{*}$ & 0.001 & $3.614(1.648,7.926)$ ** \\
\hline \multicolumn{7}{|l|}{ PBC } \\
\hline Difficult to control & $9(2.1)$ & $181(33.3)$ & 1 & - & 1 & - \\
\hline Moderate to control & $58(13.6)$ & $312(57.5)$ & 0 & $3.739(1.809,7.724)^{*}$ & 0.01 & $2.847(1.290,6.282)^{\star \star}$ \\
\hline Easy to control & $359(84.3)$ & $50(9.2)$ & 0 & $144.398(69.459,300.187)^{\star}$ & 0 & $\begin{array}{l}109.914 \quad(48.129 \\
251.016)^{\star *}\end{array}$ \\
\hline
\end{tabular}

NB: These variables are from the total variables statistical significant while cross tabulation done $(p<0.05)$ (sex, residents, education, income and perceived behavioural control)

Table 4: Bivariate and multivariate logistic regression model showing predictors of intention towards blood donation among eligible population of Dire Dawa, 2018.

\section{Discussion}

This study was assessed intention of blood donation among eligible persons. According to the theory of planned behavior intention is the immediate determinants not the actual behavior of an individual, the following discussion was based on this assumption. The overall intention of respondent's blood donation in the future of this study found $44 \%$ and the mean intention of blood donation was slightly neutral 3.36. This finding slightly higher than a study conducted in
Mekele $37 \%$ and the mean intention was 2.74 [24] and less than a study conducted in Debreberehan city $77.5 \%$ [25], in Tanzania 76.8\% [26]. This difference is may be associated with in the present study intention was assessed based on the theory of planned behaviour and multiple questionnaires were employed after conducted factor analysis. Based on the current study, the odds of intention to donate blood in the future was 1.742 times higher among male respondents than female respondents. This finding is consistent with study conducted In Mekele [24]. In Tanzania [27]. In Medical college of India [27], this difference 
might be male perceived as physically stronger and high social interaction and don't have monthly blood loss or females may not think that females does not may not think that donating blood may directly or indirectly saves the lives of herself, family or other human being who are in need of blood. The findings of the present study have revealed that high intention of blood donations (79.3\%) were seen by people who were in age group of 18 to 35 . This finding is comparable with the study conducted in Tanzania [26]. A study in Botswana younger age group was more willing to donate blood [28]. In the current study, residents of the participants were independently associated with intention of blood donation. Hence, participants who were living in urban residents 2.537 times more likely to have intention for blood donation than rural in residence. This finding is comparable with the study conducted in Tanzania [26]. The hypothesis stated in the current study was tested and the result showed, perceived Behavioral Control (PBC) is the best predictor for the intention to donate blood. In the current study perceived behavioral control was 109 times more likely intended to donate blood in the future. PBC was the strongest relationship with intention of blood donation( $\mathrm{r}=0.701)$. The result is an agreement with a research conducted in New Zealand the strongest relationship with behavioral intention was $\mathrm{PBC}(\mathrm{r}=0.63)$ [29]. Also supported by a research conducted in Malaysia [30,31]. This finding suggests that the extent to which respondents feel they can control that factors that help or hinder their ability to donate blood is more closely associated with the formation of behavioral intention than attitude and subjective norm.

\section{Limitation of the Study}

By virtue, this study is expected to be prone for the limitation of cross sectional survey or establishing causal relationship is impossible and the wider confidence interval observed with some variables may also indicate inadequate sample size. In addition, this study examined intention to blood donation and not actual behaviour. Low experiences of the community to respond for likert scale questionnaires. The study didn't separately compared donors and non-donors. The study didn't include qualitative response from concerned organization and the study participants.

\section{Conclusion}

Less than half $(44 \%)$ of study subjects were intended to donate blood in the future. From the socio-demographic characteristics age, educational level, residents, place income and from the Theory of Planned Behaviour (TPB) that has been applied in this study has proved that the theory can be a good predictor for blood donation intention especially for the population and only one Perceived behavioural control (PBC) were construct statically significant associated with intention to donate blood in the future. There is limited means of information dissemination, misconception about blood donation. Thus, FMoH and DDRHB, Blood Bank, Red Cross and religious leaders and stake holders should have to work collaboratively in order to revise developed strategies and develop new one which incorporates all the population and other researchers should have to study in community trial study in order to get more information.

\section{Acknowledgments}

We would like to thank Diredawa University, College of Medicine and Health Sciences and RTI for their technical support and giving clearance and funding to conduct this study. We are also grateful to our colleagues, who in one way or another helped us to undertake this research. As well as Dire Dawa blood bank employee Ato Esayas who helped us by providing relevant information about blood donation in the city.

\section{Competing Interests}

We declare that there are no conflicts of interest to disclose.

\section{Availability of Data and Materials}

Data will not be share in order to protect the participants' anonymity.

\section{Author's Contributions}

KA designed and implemented the study, performed the statistical analysis and drafted the manuscript. NA participated in the study design, analysis and implemented the study. All of us contributed to the data analysis, read and approved the final manuscript.

\section{Ethics Approval and Consent to Participate}

Ethical clearance was obtained from the Ethics Review Board of Dire Dawa University, on behalf of College of Medicine and Health Sciences. Ethical letter was being written to the selected health center. Informed voluntary verbal consent was obtained from each participant after giving information and thoroughly explaining the aim of the study to each respondent. The study subjects were interviewed in their homes individually to maintain privacy.

\section{Consent to Publication}

Not applicable

\section{Funding}

Financial support was obtained from research and community engagement and research and technology Institute of Diredawa University for writing the manuscript, design of the study and collection, analysis, and interpretation of data.

\section{References}

1. GDBS (1998-1999). World Health Organization Blood Transfusion Safety 1211 Geneva 27, Switzerland.

2. $100 \%$ Voluntary Blood donation: A global framework for action, World Health Organization- International Federation of Red Cross and Red Crescent Societies.

3. WHO (2001) The clinical use of blood-Handbook, Geneva 1.

4. WHO African Region. (2006). Ethiopia 2006 /Regional training workshop on blood donor recruitment: pre and post donation counselling.

5. Blood safety (2005). A global overview fact sheet Copenhagen.

6. Watanabe KK, Screiber GB, Hayes A ,Williams AE (1999) Factors influencing the recruitment and retention of young donors. Transfusion 39; A3-A20.

7. Federal Democratic Republic of Ethiopia population census commission. Summary and Statistical Report of the 2007 Addis Ababa: Central Statistical Agency 2007.

8. Central Statistical Agency (CSA). The 2007 Population and Housing Census of Ethiopia. Addis Ababa: Statistical Summary Report; 2008. 
Citation: Shibeshi KA, Ibrahim NA (2018) Predictors of Intention to Donate Blood among the Eligible Population in Dire Dawa Administration, Eastern Ethiopia: Using the Theory of Planned Behaviour . J Blood Disord Transfus 9: 410. doi:10.4172/2155-9864.1000410

Page 8 of 8

9. Trends in Maternal Mortality: 1990 to 2015 Estimates by WHO, UNICEF UNFPA, World Bank Group and the United Nations Population Division.

10. Ethiopian Demographic Health Survey, 2016.

11. UNICEF Data: Monitoring the situation of children and women. Current status progress. Maternal mortality fell by almost half between 1990 and 2015.

12. Federal democratic republic of Ethiopia, Ministry of Health. National blood transfusion services strategy, vol. Strategy, Addis Ababa, Ethiopia. 2005.

13. http://sankalpindia.net/drupal/node/320

14. Ahmed N, Kumar SR (2013) A guide to organizing a voluntary blood donation camp. Int J Blood Transfusion Immunohematology 3: 12-17.

15. Ahmed Z (2014) Knowledge, attitude and practices about blood donation among undergraduate medical students in Karachi. J Infect Dis Ther 2: 134.

16. http://www.argentinaindependen.com/currentaffairs/ newsfromargentina/more-blood-mor-life-argentinas-hunt-for-newdonors/.

17. Blood safety and availability.

18. (2012) WHO Blood supply and availability

19. (2006) World Health organization. Making Safe Blood Available in Africa.

20. (2015) Ethiopia: Blood donation, its use and means to do. The Ethiopian Herald.
21. Rosline H, Ahmed SA, Al-Joudi FS, Rapiaah M, Naing NN, et al. ( 2006) "Thalassemia among blood donor at the Hospital Universiti Sains Malaysia," Southeast Asian J Trop Med Public Health 37: 549-552.

22. AM Buyx (2009) "Blood donation, payment, and non-cash incentives: Classical questions drawing renewed interest, Transfus Med Hemother 36: 329-339.

23. http://www.who.int

24. Mirutse G, Fisseha G, Abebe L, Birhanu Z, Alemayehu M, et al. (2014) Am J Public Health Res 2: 158-163.

25. National Blood Bank Service in Ethiopia.

26. Mauka IW, Mahande JM , Msuya SE, Philemon RN (2015) Factors associated with repeat blood donation at the Northern Zone blood transfusion centre in Tanzania. J Blood Transfus 2015.

27. Chopra D, Jauhari N (2015) Knowledge attitude \& practices towards voluntary blood donation among medical students in Barabanki IJCH 27.

28. Pule Ishmael Pule (2014) Factors Associated with Intention to Donate Blood: Sociodemographic and Past Experience Variables. J Blood Transfus 2014.

29. Judith Louise. Comparisons of two approaches to predicting blood donation behavior.

30. Holdershaw J, Gendall P, Wright M (2007) Factors Influencing Blood Donation Behaviour.

31. Holdershaw J, Gendall P, Wright M (2003) Predicting Willingness to Donate Blood. AMJ 11: 87-96. 